\title{
Waste Management Model Based on Community Education in Koto Tangah Subdistrict, Padang City, Indonesia
}

\begin{abstract}
*Ernawati
Department of Geography, Universitas Negeri Padang, Indonesia

Email: ernawati@gmail.com

*Corresponding Author, Received: January 12, 2018, Revised: March 23, 2018, Accepted: April 20, 2018

This is an open acces article distributed under the Creative Commons 4.0 Aftribution License, wich permits unregtricted use, Distribution and reproduction in any medium provided the original work is properly cited @2017 by author and Universitas Negeri Padang

Abstract

This study aims to determine the perception and knowledge of the community about the sorting and waste management, by observing the behavior, and culture that influence. This research type is research of mix method, that is by combining qualitative and quantitative method. The population is all households in Koto Tangah. Sampling techniques used there are two forms of sample area (area sampling) and sample respondents. The sample of the area is taken by purposive sampling by taking 3 urban villages in Koto Tangah based on community welfare level. The sample of respondents in this study is one community group in each RW in some villages in Koto Tangah. The result of this research shows that people's perception about garbage is still relatively low, where garbage is considered as useless waste and must be discarded, some of which are waste goods are still waste product. The community's knowledge of waste is already high, but not followed by behavior on waste, especially in waste sorting. The level of public knowledge about waste management is high both in sorting and waste processing. Behavior of Koto Tangah about garbage is low, both in sorting, disposal and processing, It means there is an imbalance between people's knowledge about garbage and its behavior toward garbage.
\end{abstract}

Keywords: Perception, Knowledge, Waste, Sorting, Management

\section{Introduction}

Based on the 2015 BPS data collection released in 2016, the population of the city of Padang is about 902,000 inhabitants. This figure increased 80 thousand inhabitants compared with the results of data collection in 2014 which only around 822,000 inhabitants. Increased population, will affect the behavior / lifestyle and consumption patterns of society. Increasing population, accompanied by consumptive patterns of society, will indirectly affect the increase in volume, type and dump (Shandy, 2006; Hermon, 2014). Garbage management in Koto Tangah is currently not maximized, and limited to conventional management. This management process is handled by the Office of Sanitation and Gardening (DKP). Household waste is transported from residential areas to Temporary Disposal Sites (TPS) and then disposed of to Final Disposal (TPA) without any sorting and processing first. This means that waste processing has not been done optimally. All existing waste, both domestic and non domestic has not been done separation of waste at the source. So is the case with waste belonging to B3 waste, there has been no separation in sources and special handling for this waste (Ruslinda, 2013; Hermon, 2017). This can cause various problems both environment and society, if left in a prolonged time, because some types of municipal waste belonging to inorganic waste have a very dangerous content. Waste that is not handled properly can cause various environmental and health problems.

Conventional waste management today can not control waste. Smelly pollution from rotting garbage, water pollution from garbage disposal to rivers and leaching of leachate from landfill to settlements and water 
sources, as well as air pollution from burning waste is another problem arising from burning garbage. A pile of household waste left alone will bring in germs and disease. Garbage discharged on the road can block the waterways that make the water confined and immobile, and a place for the development of mosquitoes cause various diseases. Garbage clogging drains or sewers can cause flooding. When the floods, the water in the sewer that had been thrown out by every house will go back into the house so that all the germs, dirt and seeds of the disease into the house again. In addition, based on field observations, there are still people in Padang City who throw garbage into the river, thus directly causing pollution of river water, and the difficulty of the community to get a source of clean water, consequently also bring negative impacts on human health, such as increased diarrhea, skin diseases and so on. Thus environmental damage is more due to the behavior of people who are not concerned with the environment, especially garbage management.

Waste management aims to realize and maintain the balance of the environment by changing the way of thinking and human behavior towards waste. Establishment of environmental caring behavior can be done through informal education conducted in households through direction and examples given by the family. In addition, for the community can be done through the socialization and training provided by expert groups to community groups, with the aim that people have a correct understanding of waste management so as to have a positive impact on the environment and increased revenue. Proper waste management should start with proper management in households beginning with waste segregation. Managing the garbage that has been sorted will be more effective and efficient. But the fact that there is in Koto Tangah both in TPS and in the TPA all types of garbage mixed. So it is very difficult to process it either organic or inorganic. Conditions like this can not be separated from the condition of garbage coming from households with mixed conditions/without disaggregated. As a result, waste becomes a big problem in Koto Tangah and Padang City generally. Taking into account systematic issues in the processing of this waste, the researcher thinks it is very important to conduct an in-depth study on the behavior of people, especially households in managing waste, and provide education and training to recycle waste into products of economic value. Then, there are several alternative / waste management scenarios that can solve the environmental problems, especially the garbage problem and even the waste can be used as a source of family opinion.

\section{Method}

The location of this research is in Koto Tangah, Padang City. The population of this research is all household in Koto Tangah. The sampling technique used there are two forms: the sample area (sampling area) used to determine the part of the research area or population area to be taken, and the sample respondents will be used to determine the size of the research subject. The sample of the area is taken by purposive sampling by taking 3 urban villages in Koto Tangah based on community welfare level. The sample of respondents in this study is a group of people in each RW in some urban villages in Koto Tangah. The variables observed in this study refers to the distribution of perceptions, behavior and culture of the respondents in each sampling group. Data analysis was performed based on the frequency distribution to explain the perception and level of respondent knowledge about garbage and waste management. To test the validity and validity of data, then tested the validity and reliability test of instrument/questionnaire. To explore the background and causes of behavior in managing waste is done taking and processing data qualitatively. Data analysis researchers do since the data collection took place and after completion of data collection. At the time of the interview with the informant the researcher had done the analysis to the respondent's answer that was interviewed, after the respondent's answer was analyzed, if the researcher have not satisfied then the researcher will continue the question again until the researcher get the credible information. The components performed in data analysis is data collection, data reduction, data display, and conclusions or verification.

\section{Result and Discussion}

The public respone of waste in Kecamatan Koto Tangah can be seen from its general perspective on garbage, its perspective on the existence of garbage, the benefits of garbage, and the value of garbage. Based on the data obtained in the field about the perspective of community of Kecamatan Koto Tangah as much as 109 people $(46,78 \%)$ of respondents considered waste as waste product which is of no use, The view of this waste belongs to low category, meaning that people think that garbage is material the rest of which is 
completely useless and should be thrown away. While 124 people $(53.22 \%)$ are in moderate category, meaning that although garbage is a waste product, but a small part of this waste product can still be used. When examined in more detail from the 109 respondents who are in the low category, 78 respondents (72\%) of all low categories are located in Lubuk Buaya Village. Low category with the smallest number of respondents is in Kelurahan Balai Gadang. including low category.

While the community of Kelurahan Balai Gadang as many as 16 respondents including medium category and as many as 14 including low category. And the community Lubuk Buaya Village as many as 51 respondents including medium category and as many as 78 respondents including low category. Views of waste bungo urban village value of 67 is included in the category of moderate and as many as 7 including low category. While kelurahan hall gadang shows as many as 20 respondents included in the high category and as many as 10 respondents including low category. And village lubuk crocodile as much as 109 respondents including medium category and as many as 20 respondents including low category. For more details can be seen in table 1 below:

Table 1. Public Perceptions of Waste

\begin{tabular}{|c|c|c|c|c|c|}
\hline \multirow{2}{*}{ No } & \multirow{2}{*}{ Public Respone } & \multirow{2}{*}{ Kelurahan } & \multicolumn{3}{|c|}{ Klasification } \\
\hline & & & High & Middle & low \\
\hline \multirow[t]{3}{*}{1} & General views about waste & Bungo Pasang & & 57 & 17 \\
\hline & & Balai Gadang & & 16 & 14 \\
\hline & & Lubuk Buaya & & 51 & 78 \\
\hline \multirow[t]{3}{*}{2} & Views of existence about waste & Bungo Pasang & & 34 & 40 \\
\hline & & Balai Gadang & & 15 & 15 \\
\hline & & Lubuk Buaya & & 0 & 129 \\
\hline \multirow[t]{3}{*}{3} & Views on benefits about waste & Bungo Pasang & 58 & & 16 \\
\hline & & Balai Gadang & 24 & & 6 \\
\hline & & Lubuk Buaya & 102 & & 27 \\
\hline \multirow[t]{3}{*}{4} & Value of about waste & Bungo Pasang & & 67 & 7 \\
\hline & & Balai Gadang & 20 & & 10 \\
\hline & & Lubuk Buaya & & 109 & 20 \\
\hline
\end{tabular}

The low public perception of waste due to low understanding of the society against the value of waste and the low willingness of the community to make the waste as something that has economic value. This is in accordance with opinion According to David Krech and Richard. S. Critchfield quoted by Setiyana (2013), mentions the perception is influenced by functional factors and structural factors: (1) functional factors or personal factors are factors related to the individual's understanding of the impact of the resulting stimuli, (2) structural factors or situational factors are external factors that affect an individual's understanding of the existing stimuli. according to Setiyana (2013) structural factors can be seen from the curriculum and the implementation of subjects. Thus it can be concluded that personal and group stimuli in shaping people's perceptions can still be categorized as low, (3) community knowledge about waste management.

Based on the data in the above table it can be seen that the general knowledge about waste management in Koto Tangah is in the medium category, which is $49.4 \%$, while in the high category is $32.2 \%$ and the low category is $18.5 \%$. In the village of Bungo Pasang, the community's knowledge about the concept of garbage is in the high category, that is, 55 respondents are in high category, and 19 respondents in low category. In Balai Gadang, the community's knowledge about the concept of waste is in the high category, that is 20 respondents and 10 respondents in low category. While in the village of Lubuk Buaya community knowledge about the concept of waste is in the medium category, ie: as many as 115 respondents in the category of medium and 14 respondents in the low category. Based on the above table it can be seen that the majority of people understand the concept of waste and understand the importance of managing waste properly. This makes good capital for sustainability related to waste management in order to realize a clean environment.

In general, community knowledge about the sources and forms of waste in Koto Tangah is in the medium category, which is $82 \%$, while in the high category of $9.4 \%$ and low category of $8.6 \%$. This shows 
that in general the community has been aware of where the sources of waste and waste form, so that people can sort the waste by shape and type. In the village of Bungo Pasang, the community's knowledge about the sources and forms of waste is in the medium category that is 71 respondents and 3 respondents in the low category. In Balai Gadang urban village, the people's knowledge about the sources and forms of garbage is in the high category, that is 22 respondents and 8 respondents in low category. While in Lubuk Buaya village, the people's knowledge about the sources and forms of garbage is in the medium category, that is as much as 120 respondents and 9 respondents in low category. Public knowledge about the dangers of waste for health in Koto Tangah is in medium category, that is $99.1 \%$, and low category equal to $0,9 \%$. By knowing the dangers of garbage for the health is expected the community can better maintain the cleanliness of the environment and do not throw garbage indiscriminately, because the garbage that accumulate will cause unpleasant odor to bring disease. In the village of Bungo Pasang, the public knowledge about the dangers of garbage for health is in the medium category, namely sebanya73 respondents and 1 respondent in low category. In Balai Gadang, the community knowledge about the dangers of garbage for health is in the medium category which is 30 respondents. Whereas in Lubuk Buaya village, the community knowledge about the dangers of waste for health is in the medium category, that is 128 respondents and 1 respondent in low category.

Community knowledge about the dangers of waste for the environment in Koto Tangah is in the medium category, which is $95.3 \%$, and low category of $4.7 \%$. Garbage can pollute the environment, both land, air and water. Garbage is one of the causes of unbalanced environment, When burned will cause air pollution. In addition, the tradition of disposing garbage in the river can lead to silting that is so fast, and can cause flood because it is important to manage the waste properly so that the dangers of waste for the environment can avoided. In Bungo Pasang urban village the knowledge about the dangers of garbage for the environment is in the medium category that is as much as 72 respondents and 2 respondents in low category. Community knowledge about the benefits of waste for life in Koto Tangah is in the medium category, ie: $90.6 \%$, and low category of $9.4 \%$. Based on the above data it is known that not all people know the benefits of waste, so the waste is still regarded as something that is not useful / does not have economic value. On the village Bungo Pasang community knowledge about the benefits of waste for life is in the medium category that is as much as 70 respondents and 4 respondents in the low category. In Balai Gadang, the community knowledge about the benefit of waste for life is in the moderate category which is 21 respondents and 9 respondents in low category. While in Lubuk Buaya village, the community knowledge about the use of waste for life is in medium category, that is 120 respondents and 9 respondents in the low category.

Furthermore, people's knowledge about waste recycling for life in Koto Tangah is in high category that is 47,6 , medium category, that is equal to $29,6 \%$, and low category equal to $22,7 \%$. Based on the above data it is known that most people already know how to recycle garbage, so that the volume of waste can be suppressed. Society does not necessarily dispose of garbage, because some garbage can be recycled. In Bungo Pasang, the community knowledge about waste recycling is in the medium category, which is 69 respondents and 5 respondents in low category. In Balai Gadang, the people's knowledge about waste recycling is in the high category which is 25 respondents and 5 respondents in low category. While in Lubuk Buaya village, people's knowledge about garbage recycle is in high category, that is 86 respondents and 43 respondents low category. Public knowledge about waste recycling in Koto Tangah is in medium category, that is $81,1 \%$, and low category is $18,9 \%$. In Bungo Pasang, the community knowledge about waste recycling is in the medium category that is 71 respondents and 3 respondents in low category. In Balai Gadang, the people's knowledge about the waste recycling is in the medium category that is 22 respondents and 8 respondents in the low category. While in Lubuk Buaya village, the people's knowledge about the waste recycling is in the medium category, which is 96 respondents and 33 respondents in the low category.

Community knowledge about the obstacles in implementing waste recycling in Koto Tangah is in the medium category, that is equal to $56,7 \%$, and low category is $43,3 \%$. In the village of Bungo Pasang, the community knowledge about the obstacles in carrying out waste recycling is in the medium category that is as many as 34 respondents and 40 respondents in the low category. In Balai Gadang, the community knowledge about the obstacles in carrying out waste recycling is in the medium category that is 17 respondents and 13 respondents in the low category. While the village of Lubuk Buaya people's knowledge about the obstacles in implementing waste recycle is in the medium category, 81 respondents and 48 respondents in low category. Public knowledge of waste disposal sites in Koto Tangah is in the medium category that is $31.3 \%$, and low category of $68.7 \%$. In the village of Bungo Pasang, the community knowledge about the waste disposal site is 
in the medium category, that is 52 respondents and 22 respondents in the low category. In Balai Gadang urban village, the community knowledge about waste disposal location is in the medium category, 21 respondents, and 9 respondents in low category. While in Lubuk Buaya village, the society knowledge about waste disposal location is in low category, that is 129 respondents.

The community's knowledge about waste segregation in Koto Tangah is in the medium category, that is $82.8 \%$, and the low category is $17.2 \%$. In the village of Bungo Pasang, the community knowledge about the way of waste segregation is in the medium category that is 48 respondents and 26 respondents in low category. In Balai Gadang, the community knowledge about waste segregation is in moderate category, that is 27 respondents and 3 respondents in low category. While in Lubuk Buaya, community knowledge about waste sorting is in medium category with 118 respondents and 11 respondents in category low. Public knowledge of waste disposal in Koto Tangah is in the medium category, which is $18.9 \%$, and low category is $81.1 \%$. In the village of Bungo Pasang, the community knowledge about waste disposal is in the medium category that is 33 respondents and 41 respondents in low category. In Balai Gadang, the community knowledge about waste disposal is in the medium category that is 11 respondents, and 19 respondents in low category. While in Lubuk Buaya, community knowledge about waste disposal is in low category with 129 respondents.

Public knowledge of waste disposal time in Koto Tangah is in medium category, that is $48.1 \%$, and low category is $51,9 \%$. In the village of Bungo Pasang, the community knowledge about waste disposal time is in the medium category that is 37 respondents and 37 respondents in low category. In Balai Gadang, the community knowledge about waste disposal is in medium category, that is 24 respondents and 6 respondents in low category. While in Lubuk Buaya village, the society knowledge about waste disposal is in medium category, that is 51 respondents and 78 respondents low category. Furthermore, public knowledge about frequency of garbage disposal in Koto Tangah is in medium category, that is 50,2\%, and low category is $49,8 \%$. In the village of Bungo Pasang, the community knowledge about the frequency of garbage disposal is in the moderate category which is 47 respondents and 27 respondents in low category. In Balai Gadang, the community knowledge about the frequency of garbage disposal is in the medium category which is 25 respondents and 5 respondents in low category. While in Lubuk Buaya village, the public knowledge about the frequency of garbage disposal is in the medium category, that is 35 respondents and 84 respondents low category. The community's knowledge about the concept of $4 \mathrm{R}$ (Reuse, Reduce, Recycle and Replace) in Koto Tangah is in the medium category, ie $94.8 \%$, and low category of 5.2\%. In the village Bungo Pasang community knowledge about $4 \mathrm{R}$ (Reuse, Reduce, Recycle and Replace) are in the medium category that is as much as 74 respondents. In Balai Gadang, the community knowledge about 4R (Reuse, Reduce, Recycle and Replace) is in the medium category that is 26 respondents and 4 respondents in low category are in the moderate category, ie 121 respondents and 8 respondents in low category.

Community behavior in waste management describes community activities in community actions, experiences and understanding of waste. According to Green (1980) in (Ritohardoyo, 2006), human behavior is influenced by various actors, including basic actors covering life view, customs, beliefs and customs of society; supporting actors include education, employment, culture, strata actor; and pulling actors coming from outside themselves information. The extent to which the absorption of information by a person depends on the psychological dimension and perception of the environment to be reflected in the behavioral order. Meanwhile, according to Notoatmodjo (2007) human behavior is essentially the act or activity of the man himself who has a very wide expanse, among others; walking, talking, crying, laughing, working, college, writing, reading and so on. Based on the description, people's behavior in waste management is all human activities or activities, both observed directly and indirectly.

\section{Conclusion}

Based on the research findings and the above discussion can be concluded: (1) perception of Koto Tangah to garbage is still moderate and low. This means that people still think of it as a waste of goods that are not and less valuable that must be discarded, (2) community knowledge about waste management is high, meaning that people understand how to manage the waste is good and right, and (3) community behavior in managing waste is low, especially in the segregation of garbage, both inside and outside the home. 


\section{References}

Bungin, B. (2005). Metodologi Penelitian dan Kebijakan Publik serta Ilmi-Ilmu Sosial Lainnya. Jakarta. Prenada Media.

Chandra. (2007). Pengantar Kesehatan Lingkungan. Penerbit Buku Kedokteran Ege. Jakarta.

Creswell. J.W. (2014). Penelitian Kualitatif \& Desain Riset Memilih Diantara Lima Pendekatan. Yogyakarta. Pustaka Pelajar.

Dwiyanto. (2011). Model Peningkatan Partisipasi Masyarakat dan Penguatan Sinergi dalam Pengelolaan Sampah Perkotaan. Jurnal Ekonomi Pembangunan. Vol. 12(2): 239-256.

Hermon, D. (2014). Geografi Bencana Alam. Radjawali Press

Hermon, D. (2017). Climate Change Mitigation. Rajawali Pers (Radjagrafindo). Jakarta

Ernawati. (2015). Perilaku Peduli Lingkungan pada Sekolah Alam. Disertasi. Program Pascasarjana. UNP

Kastaman, R dan Ade M., (2006). Perancangan Reaktor Sampah Terpadu dan Pengembangan Mikroba Penghilang Bau Sampah dalam Rangka Mengatasi Masalah Sampah di Perkotaan. Fakultas Teknologi Industri Pertanian. Universitas Padjadjaran Jatinangor. Jurnal Agrikultura Vol. 17(12).

Mariana, Y., (2012). Keterlibatan Masyarakat Urban Dalam Pengolahan Sampah Rumah Tangga. Comtech. Vol. 3(2): 729-739.

Miles, M.B., \&Huberman, A.M., (1994). Analisis Data Kualitatif (Buku Sumber tentang Metode-Metode Baru). Terjemahan oleh Tjetjep Rohendi Rohidi. Jakarta. Penerbit Universitas Indonesia.

Nowosielski, R., A. Kania, and M. Spilka. (2008). Integrated Recycling Technology as A Candidate for Best Available Techniques. International Scientific Journal. Published Monthly by the World Academy of Materials and Manufacturing Engineering.

Safitri, ID. (2006). Minimasi Dampak Lingkungan dan Peningkatan Nilai Ekonomis Sampah Melalui Penentuan Lokasi Tempat Pembuangan Akhir Sampah. Jurnal PS PWK Unisba: 31-39.

Subarna, Endang. (2014). Manfaat Pengelolaan Sampah Terpadu. Aryha Eko Sinergi Persada. Surakarta.

Suryanto, Dody et al., (2005). Kajian Potensi Ekonomis dengan Penerapan 3R Pada Pengelolaan Sampah Rumah Tangga di Kota Depok. Depok.

Sugiyono. (2014). Metode Penelitian Kuantitatif Kualitatif dan R\&D. Bandung. Alfabeta.

Undang-undangRepublik Indonesia Nomor 18 Tahun 2008 Tentang Pengelolaan Sampah.

Wibowo, A., Dan D.T. Djajawinata. (2007). Jakarta. Penanganan Sampah Perkotaan Terpadu.www.kppi.go.id.

Widyatmojo, A dan S. Murdjoko. (2002). Menghindari, Mengolah dan Menyingkirkan Sampah. Abdi Tandur. Jakarta. 